\title{
Adaption of body zinc pools in weaned piglets challenged with subclinical zinc deficiency
}

\author{
Daniel Brugger* and Wilhelm M. Windisch \\ Chair of Animal Nutrition, TUM School of Life Sciences Weihenstephan, Technical University of Munich, Liesel-Beckmann- \\ Straße 2, 85354 Freising, Germany
}

(Submitted 25 August 2018 - Final revision received 6 January 2019 - Accepted 14 January 2019 - First published online 29 January 2019)

\section{Abstract}

The effects of subclinical $\mathrm{Zn}$ deficiency on depletion and redistribution of body $\mathrm{Zn}$ were studied in weaned piglets. Forty-eight weaned piglets (German-Large-White $\times$ Land-Race $\times$ Piétrain; $50 \%$ female, $50 \%$ male-castrated; body weight 8.5 (sD 0.27) kg) were fed restrictively (450 g/d) a basal maize-soyabean meal-based diet supplemented with varying amounts of $\mathrm{ZnSO}_{4} \cdot 7 \mathrm{H}_{2} \mathrm{O}$ (analysed dietary $\mathrm{Zn}: 28 \cdot 1,33 \cdot 6,38 \cdot 8,42 \cdot 7,47 \cdot 5,58 \cdot 2,67 \cdot 8$, $88.0 \mathrm{mg} / \mathrm{kg}$ diet) for an experimental period of $8 \mathrm{~d}$. Analyses comprised $\mathrm{Zn}$ concentrations in soft tissues. Statistical analyses included regression models and $k$-means cluster analysis. Jejunum and kidney $\mathrm{Zn}$ correlated positively with dietary $\mathrm{Zn}(P<0 \cdot 05)$. Other $\mathrm{Zn}$ pools responded in a nonlinear fashion by declining (colon, epidermis, spleen) or increasing (mesenteric lymph follicles, thymus, skeletal muscle) below 63.6, 48.0, 47.5, 68.0, 43.0 and $53.1 \mathrm{mg} \mathrm{Zn/kg}$ diet, respectively $(P<0 \cdot 01)$. Above these thresholds, $\mathrm{Zn}$ concentrations in epidermis, mesenteric lymph follicles and skeletal muscle plateaued $(P<0.0001)$, whereas they exhibited a decrease in colon and thymus $(P<0 \cdot 01)$ as well as a numerical increase in spleen. Clustering by dietary Zn concentration indicated clusters of varying Zn supply status and pathophysiological status. Clustering by biological matrices revealed a discrimination between storage, transport and excretion media as well as soft tissues. Taken together, novel response patterns indicated compensation reactions in tissues that are essential for the acute survival of growing animals (heart, skeletal muscle, immune tissues). Furthermore, this is to our knowledge the first study that mapped the gross $\mathrm{Zn}$ requirement by clustering tissue $\mathrm{Zn}$ concentrations between treatment groups.

\section{Key words: Subclinical zinc deficiency: Body zinc: Zinc depletion: Zinc redistribution: Pigs}

Most experimental data sets on $\mathrm{Zn}$ metabolism reflect studies that used severely Zn-depleted animals expressing symptoms of clinical $\mathrm{Zn}$ deficiency. However, this condition appears to be rare in nature and especially under livestock rearing conditions because the generous supplementation of $\mathrm{Zn}$ to feed is standard practice ${ }^{(1-\sigma)}$. Furthermore, investigations into $\mathrm{Zn}$ metabolic functions or the estimation of measures reflecting the efficacy of $\mathrm{Zn}$ feeding interventions may be biased under pathophysiological conditions because of significant secondary metabolic events. A more likely scenario of $\mathrm{Zn}$ malnutrition is a subclinical $\mathrm{Zn}$ deficiency (SZD), under which the animal expresses no visible symptoms of $\mathrm{Zn}$ depletion (e.g. growth depression, feed refusal, tissue necrosis etc. $\left.{ }^{(7)}\right)$ but significant shifts in physiological parameters ${ }^{(8-10)}$. This condition could arise through periods of fluctuating dietary Zn supply and/or increased demand (e.g. during inflammation, stress etc.). Because SZD is not accompanied by severe secondary metabolic events, it may be a more appropriate model for studies on $\mathrm{Zn}$ metabolism. Furthermore, pigs respond quite similar to dietary intervention compared to humans ${ }^{(11)}$. Therefore, an SZD model in piglets may not only be beneficial for the understanding of pig physiology but also be considered as a proper translational model for humans.
Recently, an experimental approach has been published that promotes short-term SZD in fully weaned piglets ${ }^{(8)}$. It has been shown that this condition is accompanied by a loss of digestive and antioxidative capacity ${ }^{(9-12)}$. Simultaneously, no symptoms of clinical $\mathrm{Zn}$ deficiency were evident. Furthermore, the gross $\mathrm{Zn}$ requirement under given experimental conditions was estimated at $58 \mathrm{mg} \mathrm{Zn} / \mathrm{kg} \operatorname{diet}^{(8)}$.

To better understand the $\mathrm{Zn}$ homoeostatic regulation behind these functional adaptions, this study investigated the response of $\mathrm{Zn}$ concentrations in various biological matrices in response to finely graded differences in alimentary $\mathrm{Zn}$ supply. This represents the fourth publication on the physiological response to our SZD model in weaned piglets and provides, to our knowledge, the first comparative description of tissue $\mathrm{Zn}$ concentration patterns in growing individuals as affected by short-term SZD.

\section{Methods}

This animal study was approved and registered by the responsible animal welfare authorities (District Government of Upper Bavaria, Federal State of Bavaria: case number 55.2.1.54-2532.3.63-11).

Abbreviation: SZD, subclinical zinc deficiency.

* Corresponding author: D. Brugger, fax +49 816171 5367, email daniel.brugger@wzw.tum.de. 


\section{Animals and diets}

This is the fourth publication based on an experiment setup that has been described in detail earlier ${ }^{(8)}$. In brief, forty-eight fully weaned piglets (hybrids of German Large White $\times$ Land Race $\times$ Piétrain; $50 \%$ female, $50 \%$ male-castrated; initial average body weight 8.5 (SD 0.27) kg, supplier: pig farm of Christian Hilgers (Germany)) from six litters were fed a $\mathrm{Zn}$ adequate $(60 \mathrm{mg}$ added $\mathrm{Zn} / \mathrm{kg}$ as $\mathrm{ZnSO}_{4} .7 \mathrm{H}_{2} \mathrm{O}$ yielding $88.0 \mathrm{mg}$ analysed $\mathrm{Zn} / \mathrm{kg}$ diet) maize-soyabean meal-based diet ad libitum, during a 2 -week acclimatisation phase (Table 1). Subsequently, animals were subject to eight different treatment groups $(n 6)$ by a balanced distribution of litter mates, sex and body weight (blocking). These groups received restrictively $(450 \mathrm{~g} / \mathrm{d})$ the same basal diet ( $28.1 \mathrm{mg}$ native $\mathrm{Zn} / \mathrm{kg}$ diet) as during acclimatisation but with finely graded differences in dietary $Z n$ supply $(0,5,10,15,20,30$, $40,60 \mathrm{mg}$ added $\mathrm{Zn} / \mathrm{kg}$ diet from $\mathrm{ZnSO}_{4} .7 \mathrm{H}_{2} \mathrm{O}$ yielding $28 \cdot 1$, $33 \cdot 6,38 \cdot 8,42 \cdot 7,47 \cdot 5,58 \cdot 2,67 \cdot 8,88 \cdot 0 \mathrm{mg}$ total $\mathrm{Zn} / \mathrm{kg}$ diet) for a total experimental period of $8 \mathrm{~d}$. The highest supplied group ( $88.0 \mathrm{mg} \mathrm{Zn} / \mathrm{kg}$ ) was considered as control because it represented the supply level fed during the 2 weeks of acclimatisation. The individual animal represented the experimental unit. Animals were handled and assessed block-wise to avoid bias.

\section{Sampling conditions}

After eight experimental days, all animals were killed without fasting by exsanguination under anaesthesia (azaperone and ketamine), block-wise to avoid bias. Sampling procedures for feed, faeces, blood plasma, bone and soft tissues have been described earlier ${ }^{(8)}$. In brief, each experimental diet was sampled in individual airtight polyethylene bottles. Faecal, bone and soft tissue samples were collected in plastic bags and vacuumed. Li-heparin blood was centrifuged $\left(1100 \mathrm{~g}, 4^{\circ} \mathrm{C}, 10 \mathrm{~min}\right)$ and the plasma was collected in Eppendorf tubes. All samples were stored at $-20^{\circ} \mathrm{C}$ until analysis.

\section{Chemical analyses}

All samples were subject to DM and total $\mathrm{Zn}$ analysis as described in Brugger et al. ${ }^{(8)}$ Quantification of total Zn occurred by atomic absorption spectrophotometry (AAS) (NovAA 350, Analytik Jena AG) using a certified external AAS Zn standard (Merck 109953, Merck Millipore) after microwave wet digestion (Ethos 1, MLS GmbH).

\section{Statistical analyses}

All statistical procedures were performed with SAS 9.4 (SAS Institute Inc.). Linear broken-line regression models $(y=a+b x$; $y=a+b x+c x)$ were calculated for tissue $\mathrm{Zn}$ concentrations in response to changes in dietary $\mathrm{Zn}$ concentration (procedure NLMIXED) using individual group means ( $n$ 8). Using single values from individual animals for regression analysis was not advisable, given the present experimental design as the imbalance in the ratio of $X$ (eight dietary treatment groups) and $Y$ (six response values per treatment group) would have caused a severe overestimation of the $\mathrm{df}$ and, therefore, false results. The broken-line regression approach represents an iterative procedure to estimate a potential dietary threshold (breakpoint) within non-linear data sets above and below which, respectively, a significant difference in the response behaviour of a certain parameter to the dietary treatment is evident ${ }^{(13)}$. If no significant breakpoint in parameter response could be estimated from respective data sets, a linear regression was calculated instead $(y=a+b x)$ (procedure REG). Only significant regression models were applied for data presentation and interpretation. A threshold of $P \leq 0.05$ was considered to be significant.

Finally, $k$-means cluster analyses of tissue Zn concentrations were performed by applying the procedure FASTCLUS assuming $k=6$ and 5 clusters for clustering according to classification variables 'dietary $\mathrm{Zn}$ concentration' and 'type of biological matrix', respectively. In addition, the procedure FREQ was applied for frequency tabulation of the $k$-means clusters with the respective classification variable. Graphical display of the discriminatory power of $k$-means clusters was achieved by canonical discriminant analysis of the cluster data using the procedure CANDISC and plotting of canonical variables Can $1 v$. Can 2. The FASTCLUS and CANDISC procedure provide statistical measures of the goddess of fit of respective $k$-means

Table 1. Composition as well as concentrations of metabolisable energy and crude nutrients of the basal diet ${ }^{(8)}$

\begin{tabular}{|c|c|c|c|}
\hline \multicolumn{2}{|l|}{ Dietary composition } & \multicolumn{2}{|l|}{ Chemical composition } \\
\hline Maize (\%) & $46 \cdot 0$ & Analysed values & \\
\hline Soyabean meal ( $40 \%$ crude protein) (\%) & $26 \cdot 0$ & DM (g/kg diet) & 902 \\
\hline Potato protein $(\%)$ & $10 \cdot 0$ & Crude protein (g/kg diet) & 238 \\
\hline Wheat bran (\%) & 5.00 & Total lipids ( $\mathrm{g} / \mathrm{kg}$ diet) & $45 \cdot 7$ \\
\hline Sugar beet pulp (\%) & 3.00 & Crude fibre ( $\mathrm{g} / \mathrm{kg}$ diet) & $51 \cdot 2$ \\
\hline $\operatorname{Premix}^{*}(\%)$ & $2 \cdot 70$ & Crude ash (g/kg diet) & 61.0 \\
\hline Feeding sugar (\%) & 2.00 & Estimated valuest & \\
\hline Soyabean oil (\%) & 1.50 & Metabolisable energy (MJ/kg diet) & $13 \cdot 3$ \\
\hline $\mathrm{Ca}\left(\mathrm{H}_{2} \mathrm{PO}_{4}\right)_{2}(\%)$ & 1.60 & Lys (g/kg diet) & $13 \cdot 8$ \\
\hline $\mathrm{CaCO}_{3}(\%)$ & 1.40 & Met ( $\mathrm{g} / \mathrm{kg}$ diet) & $4 \cdot 10$ \\
\hline $\mathrm{NaCl}(\%)$ & 0.50 & Thr (g/kg diet) & $10 \cdot 3$ \\
\hline $\mathrm{TiO}_{2}(\%)$ & 0.30 & $\operatorname{Trp}(\mathrm{g} / \mathrm{kg}$ diet) & 2.90 \\
\hline
\end{tabular}

* Premix composition: $2.80 \% \mathrm{MgO} ; 0.08 \% \mathrm{CuSO}_{4} .5 \mathrm{H}_{2} \mathrm{O} ; 2.00 \% \mathrm{FeSO}_{4} .7 \mathrm{H}_{2} \mathrm{O} ; 0.20 \% \mathrm{MnSO}_{4} \cdot \mathrm{H}_{2} \mathrm{O} ; 0.002 \% \mathrm{Na}_{2} \mathrm{SeO}_{3} .5 \mathrm{H}_{2} \mathrm{O} ; 0.002 \% \mathrm{KI} ; 0.05 \%$ retinyl propionate; $0.007 \%$ cholecalciferol; $0.20 \%$ all-rac-a-tocopherol; $0.002 \%$ menadione; $0.01 \%$ thiamine; $0.03 \%$ riboflavin; $0.10 \%$ nicotinic acid; $0.02 \%$ pantothenic acid; $0.02 \%$ pyridoxine; $0.15 \%$ hydroxocobalamin; $0.03 \%$ biotin; $0.002 \%$ folic acid; $6.70 \%$ choline; $77.6 \%$ maize meal.

† The concentrations of metabolisable energy and essential pre-caecal digestible (synonymous with 'ileal digestible') amino acids were estimated according to feed table information (http://datenbank.futtermittel.net/). Vitamin and trace element concentrations (except $\mathrm{Zn}$ ) met the requirements according to the National Research Council ${ }^{(10)}$. 
clustering models (approximate expected overall coefficient of determination $\left(R^{2}\right)$, cubic clustering criterion (CCC)) as well as a $P$ value regarding the significance of differences between clusters. These measures have been presented within respective figures.

The justification of the total sample size for the present experiment has been done earlier on base of plasma and liver $\mathrm{Zn}$ status parameters ( $\mathrm{Zn}$ concentrations, enzyme activities, gene expression patterns) ${ }^{(8)}$. Based on these assumptions it has been concluded that forty-eight animals in a completely randomised block design yielded in any case a statistical power of $1-\beta>0 \cdot 8$, which is generally accepted to represent the minimum power for studies on the kinetics and dynamics of substances within animal organisms ${ }^{(14)}$. For the present data sets, which have been analysed using linear and non-linear regression models to compare the response of group means over dietary doses, we used the SAS 9.4 procedure POWER to justify this approach. Based on these estimations, the underlying effect sizes of presented models as well as for $t$ tests (included in the procedures REG and NLMIXED) on the significance of certain statistical measures of these curves (slopes, breakpoints) exceeded in any case the minimum statistical power of $0 \cdot 8$.

\section{Results}

All animals developed equally during the whole trial period and expressed no signs of impaired health and well-being or other adverse effects (no signs of feed refusal, growth depression etc. $\left.{ }^{(7)}\right)^{(8)}$.

Fig. 1 highlights the response of tissue $\mathrm{Zn}$ concentration in jejunum, colon, mesenteric lymph follicles, thymus, spleen, skeletal muscle, kidney and epidermis in weaned piglets fed diets with varying dietary $\mathrm{Zn}$ concentration for $8 \mathrm{~d}$. The statistical measures of the respective regression curves are shown in Table 2 .

Zn concentrations in jejunum and kidney followed a straight linear response with significant positive slopes over the full range of applied dietary $\mathrm{Zn}$ concentrations $(P=0.04,0.004$, respectively). The remaining tissue $\mathrm{Zn}$ concentrations exhibited a non-linear behaviour in response to changes in dietary $\mathrm{Zn}$ concentration. Break points were evident based on significant estimates for $X$ and $Y$ intercepts of respective thresholds ( $X$-intercept ( $\mathrm{mg} \mathrm{Zn/kg} \mathrm{diet)} \mathrm{and} Y$-intercept $(\mathrm{mg} \mathrm{Zn} / \mathrm{kg}$ tissue DM): 63.6 and $94.4,68.0$ and 59.2, 43.0 and 56.9, 47.5 and 60.5, 53.1 and 52.7 and 48.0 and 40.8 for colon, mesenteric lymph follicles, thymus, spleen, skeletal muscle and epidermis, respectively; $P<0.001$ in all cases).

Above these break points, the response of total $\mathrm{Zn}$ concentration in mesenteric lymph follicles, skeletal muscle and epidermis plateaued in response to changes in dietary $\mathrm{Zn}$ concentration, whereas the $\mathrm{Zn}$ concentrations in colon, thymus and spleen correlated positively or negatively, respectively, with the dietary $\mathrm{Zn}$ concentration $(P=0.001,0.006,0.24$, respectively).

Below the respective breakpoints, the $\mathrm{Zn}$ concentrations in colon, spleen and epidermis exhibited a direct relationship $(P<0.0001, P=0.22, \quad P=0.14)$, whereas mesenteric lymph follicles, thymus and skeletal muscle followed an inverse response to further reduction in dietary $\mathrm{Zn}$ concentration $(P=0.03,0.003,0.13$, respectively). In case of colon $\mathrm{Zn}$, the data points of the groups receiving 28.1 and $33.6 \mathrm{mg} \mathrm{Zn/kg} \mathrm{diet}$ were excluded from the estimation of the broken-line regression model because they seemed to exhibit a distinct status of $\mathrm{Zn}$ homoeostatic regulation. This aspect has been further addressed within the 'Discussion' section.

The subsequently presented cluster analysis also included $\mathrm{Zn}$ concentrations in other matrices. These data sets have been published and discussed earlier ${ }^{(8-10,12)}$. The respective response patterns over dietary $\mathrm{Zn}$ concentrations are highlighted in online Supplementary Fig. S1 and Supplementary Table S1.

Fig. 2 presents $k$-means cluster analysis of $\mathrm{Zn}$ concentration patterns in various biological matrices (soft tissue, bone, blood plasma, faeces) in weaned piglets fed diets with different $\mathrm{Zn}$ concentrations for $8 \mathrm{~d}$. Tables 3 and 4 highlight the frequency tabulation of $k$-mean clusters with respective classification variables ('dietary Zn concentration', 'type of biological matrix') in addition to Fig. 2(a) and (b), respectively.

Cluster analyses according to classification variable 'dietary Zn concentration' (Fig. 2(a) and Table 3) as well as 'type of biological matrix' (Fig. 2(b) and Table 4) yielded CCC values $>3$, respectively, which is generally accepted as indicator of good clustering ${ }^{(15)}$. Furthermore, in both cases significant differences between clusters were evident $(P<0 \cdot 0001)$.

Fig. 2(a) indicates a clear discrimination between each of the six clusters by canonical variable 1 (Can 1), whereas Can 2 only discriminated between cluster 1 and the sum of clusters 2, 3 and 6 . Clusters 1-3 represent exclusively animals which were fed below the gross $\mathrm{Zn}$ requirement threshold under the present experimental conditions ( $58 \mathrm{mg} \mathrm{Zn} / \mathrm{kg}$ diet), whereas clusters 4-6 contain only the sufficiently supplied groups ( $\geq 58 \mathrm{mg} \mathrm{Zn/kg}$ diet) (Tables 3). Frequency tabulation of data points further indicated the following gradual distribution of deficiently supplied groups over clusters: $100 \%$ of values from $28.1 \mathrm{mg} \mathrm{Zn/kg}$ diet group associated with cluster $1 ; 33.3$ and $66.7 \%$ of values from $33.6 \mathrm{mg} \mathrm{Zn/kg} \mathrm{diet} \mathrm{group} \mathrm{associated} \mathrm{with} \mathrm{clusters} 1$ and 2, respectively; 66.7 and $33.3 \%$ of values from $38.8 \mathrm{mg} \mathrm{Zn} / \mathrm{kg}$ diet group associated with clusters 2 and 3 , respectively; 16.7 and $83.3 \%$ of values from $42.7 \mathrm{mg} \mathrm{Zn} / \mathrm{kg}$ diet group associated with clusters 2 and 3, respectively; $100 \%$ of values from $47.5 \mathrm{mg}$ $\mathrm{Zn} / \mathrm{kg}$ diet group associated with cluster 3 . Clusters 4 and 6 are predominately represented by animals receiving either 58.2 or $67 \cdot 8 \mathrm{mg} \mathrm{Zn} / \mathrm{kg}$ diet in ratios of $16 \cdot 7: 83 \cdot 3$ and $66 \cdot 7: 33 \cdot 3$, respectively. The highest supplied group was associated with $16.7 \%$ of values to cluster 4 , whereas $83.3 \%$ represented cluster 5 .

According to Fig. 2(b), Can 1 discriminated between clusters $1,2,3$ as well as the sum of clusters 4 and 5. In contrast, Can 2 discriminated between cluster 2 and the sum of clusters 1, 3, 4 and 5. Frequency tabulation indicated clusters 1,2 and 3 to be exclusively represented by the biological matrices faeces, femur and blood plasma, respectively, with the values of the latter cluster being almost congruent. Clusters 4 and 5 are exclusively represented by soft tissues in following percentage amounts: $100 \%$ of heart muscle, skeletal muscle, mesenteric lymph nodes, spleen and epidermis as well as 50 and $83.3 \%$ of kidney 
(a)
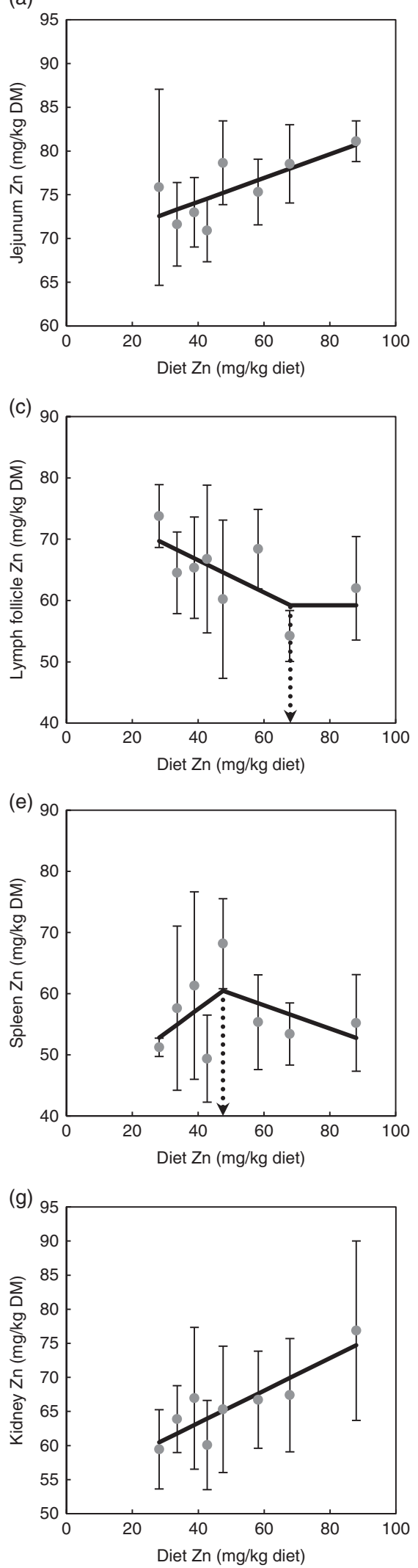

(b)

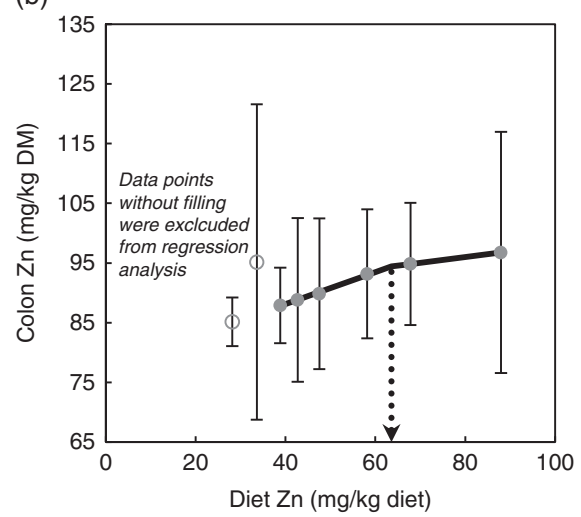

(d)

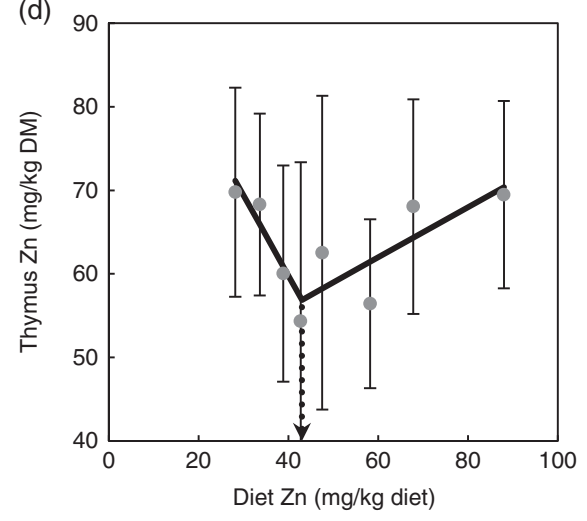

(f)

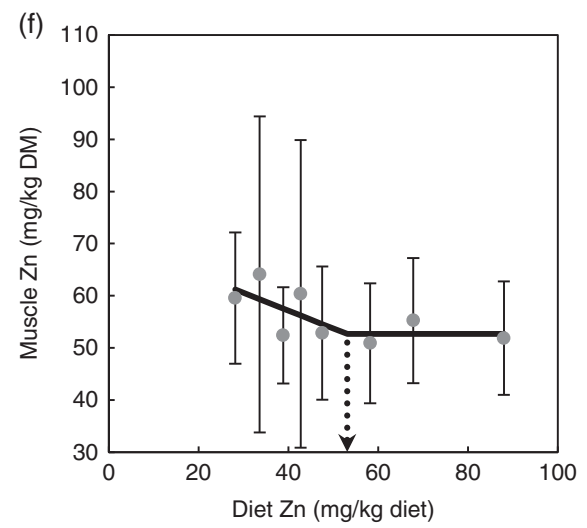

(h)

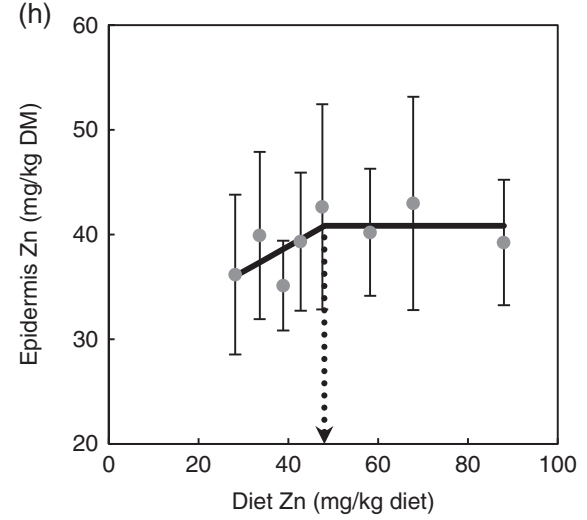

Fig. 1. Response of zinc concentrations in jejunum (a), colon (b), mesenteric lymph follicles (c), thymus (d), spleen (e), skeletal muscle (f), kidney (g) and epidermis (h) in weaned piglets fed diets with different zinc concentrations for $8 \mathrm{~d}$ (see Table 2 for detailed information on the statistical measures of the respective regression curves). Notes: values are arithmetic means and standard deviations, $n$ 6. (a, g) , Group mean and standard deviation; —, linear regression. (b-f, h) e, Group mean and standard deviation; —_, broken-line regression. 
Table 2. Linear and broken-line regression analysis of tissue zinc concentrations of jejunum, kidney, colon, epidermis, skeletal muscle, mesenteric lymph follicle, thymus and spleen in weaned piglets fed diets with different zinc concentrations for $8 \mathrm{~d} \dagger$ (Mean values with their standard errors)

\begin{tabular}{|c|c|c|c|c|}
\hline & Regression model & Parameter estimates (mg Zn/kg tissue DM) & SE & $R^{2}$ \\
\hline Jejunum & $y=68 \cdot 7+b x$ & $b 0 \cdot 14^{*}$ & 0.05 & 0.55 \\
\hline \multirow[t]{4}{*}{ Colon } & $y=77 \cdot 4+b_{1} x$ for $x \leq X_{\mathrm{B}}$ & $X_{\mathrm{B}} 63 \cdot 6^{\star \star \star}$ & 2.43 & 0.99 \\
\hline & $y=88.4+b_{2} x$ for $x>X_{\mathrm{B}}$ & $Y_{\mathrm{B}} 94.4^{\star \star \star}$ & 0.49 & \\
\hline & & $b_{1} 0 \cdot 27^{\star \star \star}$ & 0.02 & \\
\hline & & $b_{2} 0 \cdot 10^{\star \star \star}$ & 0.02 & \\
\hline \multirow[t]{3}{*}{ Mesenteric lymph follicle } & $y=77 \cdot 1+b_{1} x$ for $x \leq X_{\mathrm{B}}$ & $X_{\mathrm{B}} 68 \cdot 0^{\star \star *}$ & 0.02 & 0.47 \\
\hline & $y=Y_{\mathrm{B}}$ for $x>X_{\mathrm{B}}$ & $Y_{\mathrm{B}} 59 \cdot 2^{\star \star \star}$ & 2.41 & \\
\hline & & $b_{1}-0 \cdot 26^{*}$ & $0 \cdot 10$ & \\
\hline \multirow[t]{4}{*}{ Thymus } & $y=98 \cdot 1+b_{1} x$ for $x \leq X_{\mathrm{B}}$ & $X_{\mathrm{B}} 43 \cdot 0^{\star \star \star}$ & 0.008 & 0.73 \\
\hline & $y=44 \cdot 0+b_{2} x$ for $x>X_{\mathrm{B}}$ & $Y_{\mathrm{B}} 56 \cdot 9^{\star \star \star}$ & 1.82 & \\
\hline & & $b_{1}-0.96^{\star \star}$ & 0.23 & \\
\hline & & $b_{2} 0.30^{\star \star}$ & 0.08 & \\
\hline \multirow[t]{4}{*}{ Spleen } & $y=41.6+b_{1} x$ for $x \leq X_{\mathrm{B}}$ & $X_{\mathrm{B}} 47 \cdot 5^{\star \star \star}$ & 0.01 & 0.22 \\
\hline & $y=69.5+b_{2} x$ for $x>X_{\mathrm{B}}$ & $Y_{\mathrm{B}} 60 \cdot 5^{\star \star \star}$ & $3 \cdot 24$ & \\
\hline & & $b_{1} 0.40$ & 0.3 & \\
\hline & & $b_{2}-0.19$ & 0.15 & \\
\hline \multirow[t]{3}{*}{ Skeletal muscle } & $y=70.9+b_{1} x$ for $x \leq X_{\mathrm{B}}$ & $X_{\mathrm{B}} 53 \cdot 1^{\star \star}$ & 11.4 & 0.49 \\
\hline & $y=Y_{\mathrm{B}}$ for $x>X_{\mathrm{B}}$ & $Y_{\mathrm{B}} 52 \cdot 7^{\star \star \star}$ & $1 \cdot 87$ & \\
\hline & & $b_{1}-0.34$ & 0.21 & \\
\hline Kidney & $y=53 \cdot 8+b x$ & $b 0.24^{\star \star}$ & 0.05 & 0.77 \\
\hline \multirow[t]{3}{*}{ Epidermis } & $y=29 \cdot 2+b_{1} x$ for $x \leq X_{\mathrm{B}}$ & $X_{\mathrm{B}} 48 \cdot 0^{\star \star \star}$ & 8.96 & 0.43 \\
\hline & $y=Y_{\mathrm{B}}$ for $x>X_{\mathrm{B}}$ & $Y_{\mathrm{B}} 40 \cdot 8^{\star \star *}$ & $1 \cdot 19$ & \\
\hline & & $b_{1} 0.24$ & 0.15 & \\
\hline
\end{tabular}

$\mathrm{SE}$, standard error of respective parameter estimates; $R^{2}$, coefficient of determination; $b$, slope of the parameter response of the linear regression curves; $X_{\mathrm{B}}, X$ intercept of the break point in parameter response; $Y_{\mathrm{B}}, Y$ intercept of the break point in parameter response; $b_{1}$, slope of the broken-line regression curves over dietary $Z \mathrm{n}$ doses $\leq X_{\mathrm{B}} ; b_{2}$, slope of the broken-line regression curves over dietary $\mathrm{Zn}$ doses $>X_{\mathrm{B}}$.

${ }^{\star} P<0.05,{ }^{* \star} P<0.01,{ }^{\star \star \star} P<0.0001$. Linear and broken-line regression models were estimated based on independent arithmetic group means relative to dietary $\mathrm{Zn}$ concentration ( $n$ 8; except for colon where the two lowest supplied groups were excluded from the analyses $\rightarrow n 6$ ). Parameter estimates are presented as means with their standard errors to indicate the precision of estimation. $P \leq 0.05$ was considered to be significant.

† The applied dietary $\mathrm{Zn}$ concentrations were $28 \cdot 1$, 33.6, 38.8, 42.7, 47.5, 58.2, 67.8 and $88.0 \mathrm{mg} \mathrm{Zn/kg}$.

and thymus, respectively, were associated with cluster 4; $100 \%$ of fundus, jejunum, colon, liver and pancreas as well as 50 and $16.7 \%$ of kidney and thymus, respectively, were associated with cluster 5 .

\section{Discussion}

This study investigated the depletion and redistribution of body $\mathrm{Zn}$ in weaned piglets challenged with short-term SZD. Therefore, changes in $\mathrm{Zn}$ concentrations of several soft tissues as well as bone, plasma and faeces in response to finely graded differences in dietary $\mathrm{Zn}$ supply for $8 \mathrm{~d}$ were monitored. The suitability of our experimental design to induce SZD in weaned piglets has been discussed in detail in earlier publications ${ }^{(8,9)}$.

The $\mathrm{Zn}$ concentrations within the biological matrices examined during the present study showed either a significant linear or non-linear pattern in response to changes in dietary $\mathrm{Zn}$ concentration. There was no tissue fraction that was not affected by the dietary treatment, which is in sharp contrast to earlier studies using models of clinical $\mathrm{Zn}$ deficiency. For example, it has been reported earlier that total $\mathrm{Zn}$ concentrations in heart, spleen and thymus were not affected by changes in alimentary Zn supply ${ }^{(16-18)}$

Muscle tissues (heart, skeletal) as well as immune tissues (mesenteric lymph follicles, thymus) exhibited a response pattern to varying dietary $\mathrm{Zn}$ supply which to our knowledge has been reported earlier only for the total $\mathrm{Zn}$ pool (but not the $\mathrm{Zn}$ concentration) within the skeletal muscle of clinical Zn-deficient growing rats ${ }^{(16)}$. These tissues either replenished their $\mathrm{Zn}$ concentrations after an initial depletion phase (heart, thymus) or even exceeded the control level (muscle, mesenteric lymph follicles) under the terms of deficient alimentary supply. This was to some extent also the case in pancreatic tissue, which has been demonstrated by Brugger \& Windisch ${ }^{(9,12)}$. In the case of heart muscle, the repletion of tissue $\mathrm{Zn}$ concentrations in deficiently Zn supplied groups correlated with higher proapoptotic and antioxidative gene expression, which has been concluded to compensate for a significant loss in the tissue's ability to detoxify reactive oxygen species ${ }^{(10)}$. Indeed, $\mathrm{Zn}$ is essential for basic cellular processes like the regulation of gene transcription or the maintenance of DNA integrity ${ }^{(19)}$. Therefore, we conclude that the response of $\mathrm{Zn}$ concentrations in muscle and immune tissues of $\mathrm{Zn}$-depleted animals may also represent a compensation reaction. It is interesting that this kind of behaviour was mainly evident in organs that are supposed to be essential for the acute survival of the organism (heart, skeletal muscle, immune tissue and pancreas). Obviously, these tissues acted as $\mathrm{Zn}$ acceptors at the expense of other tissues, which released parts of their total $\mathrm{Zn}$ load to the periphery and/or reduced $\mathrm{Zn}$ uptake from the circulation (e.g. bone, kidney, liver, epidermis).

The non-linear response of spleen $\mathrm{Zn}$ concentration in the present study might have reflected an increased degradation of white blood cells and associated recycling of $\mathrm{Zn}$ released from degraded immune cells. This would be in context to Hosea 
(a)

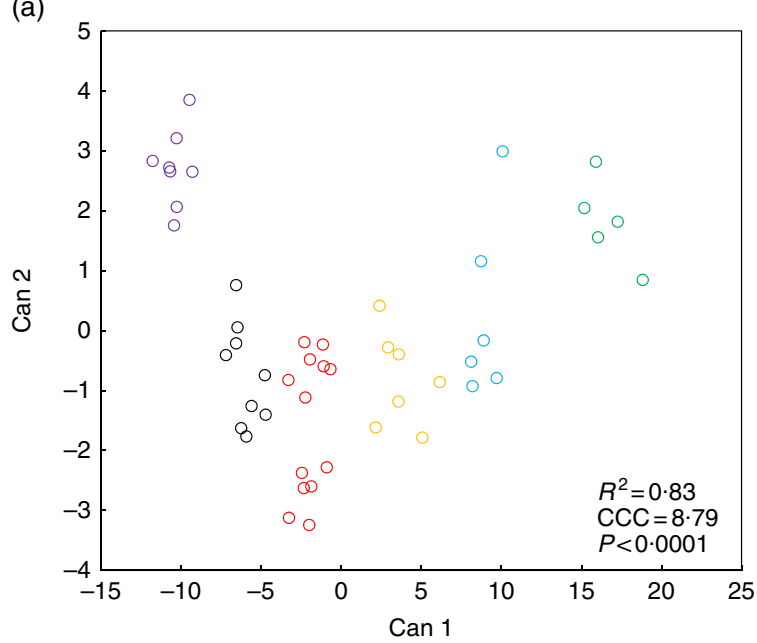

(b)

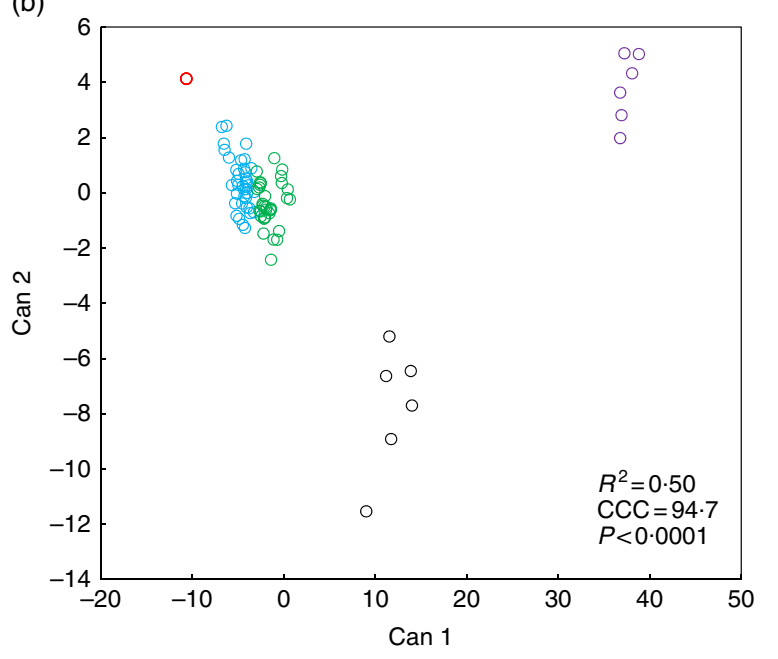

Fig. 2. $K$-means cluster analysis according to dietary zinc concentration (a) and type of biological matrix (b) of $\mathrm{Zn}$ concentration patterns in distinct types of biological matrices of weaned piglets fed diets with varying $\mathrm{Zn}$ concentration for $8 \mathrm{~d}$ (see Tables 3 and 4 for frequency tabulation of clusters according to the respective classification variables). Notes: Can, canonical variable; CCC, cubic clustering criterion; $R^{2}$, approximate expected overall coefficient of determination of the respective $k$-means clustering model. Data analysis comprised $\mathrm{Zn}$ concentrations from fifteen different biological matrices (faeces, femur, blood plasma, fundus, jejunum, colon, liver, kidney, pancreas, heart muscle, skeletal muscle, thymus, mesenteric lymph nodes, spleen and epidermis) sampled from forty-eight weaned piglets receiving finely graded differences in dietary $\mathrm{Zn}$ concentration (28.1, 33.6, 38.8, 42.7, 47.5, 58.2, 67.8 and $88.0 \mathrm{mg} \mathrm{Zn/kg} \mathrm{diet,} \mathrm{respectively;} n 6$ animals per feeding group) yielding a total of 720 single data points; a total number of clusters of $k=6$ and 5 for clustering according to tissue zinc concentration and type of biological matrix, respectively, yielded the best results in terms of cluster discrimination using the FASTCLUS procedure of SAS 9.4; a cubic clustering criterion $>3$ is considered to represent good clustering of a data set ${ }^{(15)} ; P<0.0001$ indicates significant differences between certain clusters. $\bigcirc$, Cluster $1 ; O$, cluster $2 ; \bigcirc$, cluster $3 ; \bigcirc$, cluster $4 ; \bigcirc$, cluster $5 ; \bigcirc$, cluster 6 .

et al. ${ }^{(20)}$ who recognised a decrease in T cells and B cells within the spleen of $\mathrm{Zn}$-deficient growing rats. However, this hypothesis is yet to be tested. Furthermore, an earlier study on the time course of SZD in rats recognised a stepwise decrease in spleen $\mathrm{Zn}$ concentration ${ }^{(21)}$, however, other groups did not recognise any changes ${ }^{(17,18)}$. Future experiments should
Table 3. Cross-tabulation of absolute and relative numbers of withincluster mean values with the classification variable 'dietary $\mathrm{Zn}$ concentration' associated with a total of $k=6$ clusters after $k$-means cluster analysis of $\mathrm{Zn}$ concentrations in fifteen biological matrices from forty-eight weaned piglets fed varying dietary zinc concentrations* (Numbers and percentages)

\begin{tabular}{|c|c|c|c|c|c|c|}
\hline \multirow[b]{2}{*}{ Diet Zn (mg/kg) } & \multicolumn{6}{|c|}{ Clusters } \\
\hline & 1 & 2 & 3 & 4 & 5 & 6 \\
\hline \multicolumn{7}{|l|}{28.1} \\
\hline$n$ & 6.00 & 0 & 0 & 0 & 0 & 0 \\
\hline$\%$ & 100 & 0 & 0 & 0 & 0 & 0 \\
\hline \multicolumn{7}{|l|}{33.6} \\
\hline$n$ & 2.00 & 4.00 & 0 & 0 & 0 & 0 \\
\hline$\%$ & 33.3 & $66 \cdot 7$ & 0 & 0 & 0 & 0 \\
\hline \multicolumn{7}{|l|}{38.8} \\
\hline$n$ & 0 & 4.00 & 2.00 & 0 & 0 & 0 \\
\hline$\%$ & 0 & 66.7 & 33.3 & 0 & 0 & 0 \\
\hline \multicolumn{7}{|l|}{$42 \cdot 7$} \\
\hline$n$ & 0 & 1.00 & 5.00 & 0 & 0 & 0 \\
\hline$\%$ & 0 & $16 \cdot 7$ & $83 \cdot 3$ & 0 & 0 & 0 \\
\hline \multicolumn{7}{|l|}{47.5} \\
\hline$n$ & 0 & 0 & 6.00 & 0 & 0 & 0 \\
\hline$\%$ & 0 & 0 & 100 & 0 & 0 & 0 \\
\hline \multicolumn{7}{|l|}{$58 \cdot 2$} \\
\hline$n$ & 0 & 0 & 0 & 1.00 & 0 & 5.00 \\
\hline$\%$ & 0 & 0 & 0 & $16 \cdot 7$ & 0 & 83.3 \\
\hline \multicolumn{7}{|l|}{$67 \cdot 8$} \\
\hline$n$ & 0 & 0 & 0 & 4.00 & 0 & 2.00 \\
\hline$\%$ & 0 & 0 & 0 & $66 \cdot 7$ & 0 & 33.3 \\
\hline \multicolumn{7}{|l|}{88.0} \\
\hline$n$ & 0 & 0 & 0 & 1.00 & 5.00 & 0 \\
\hline$\%$ & 0 & 0 & 0 & $16 \cdot 7$ & $83 \cdot 3$ & 0 \\
\hline
\end{tabular}

reproduce the spleen $\mathrm{Zn}$ response from the present study and investigate its mode of action.

In some earlier studies, the $\mathrm{Zn}$ concentrations within kidney and urine did not significantly respond to changes in dietary $\mathrm{Zn}$ supply $^{(18,22,23)}$. Therefore, the relevance of the kidney for the regulation of whole-body $\mathrm{Zn}$ homoeostasis was considered to be less important. However, a stable $\mathrm{Zn}$ load in times of fluctuating demands and/or supply levels, respectively, indicates a strict control of renal $\mathrm{Zn}$ fluxes. Given the timescale of earlier studies (approximately 2 weeks of insufficient dietary Zn supply), a lack in responsiveness of kidney/urinary Zn may indicate an end point in homoeostatic adaption to clinical $\mathrm{Zn}$ deficiency. Hence, under such conditions urinary $\mathrm{Zn}$ may represent inevitable endogenous losses (e.g. from sloughed nephric endothelial cells). However, the response of kidney $\mathrm{Zn}$ concentrations indicates a direct functional relationship to the status of bone $\mathrm{Zn}$ stores under the present experimental conditions. This decrease in $\mathrm{Zn}$ concentration may have happened in favour of other tissues (heart, skeletal muscle, thymus, mesenteric lymph follicles and pancreas) to compensate shortterm $\mathrm{Zn}$ losses. This supports the data of Canton \& Cremin ${ }^{(21)}$ who also recognised a decrease in the concentrations of renal $\mathrm{Zn}$ in parallel to bone $\mathrm{Zn}$ in the course of SZD in the rat. Own 
Table 4. Cross-tabulation of absolute and relative numbers of withincluster mean values with the classification variable type of biological matrix' associated with a total of $k=5$ clusters after $k$-means cluster analysis of $\mathrm{Zn}$ concentrations in fifteen biological matrices from forty-eight weaned piglets fed varying dietary zinc concentrations*

(Numbers and percentages)

\begin{tabular}{|c|c|c|c|c|c|}
\hline \multirow{2}{*}{ Type of biological matrix } & \multicolumn{5}{|c|}{ Cluster } \\
\hline & 1 & 2 & 3 & 4 & 5 \\
\hline \multicolumn{6}{|l|}{ Faeces } \\
\hline$n$ & 6.00 & 0 & 0 & 0 & 0 \\
\hline$\%$ & 100 & 0 & 0 & 0 & 0 \\
\hline \multicolumn{6}{|l|}{ Femur } \\
\hline$n$ & 0 & 6.00 & 0 & 0 & 0 \\
\hline$\%$ & 0 & 100 & 0 & 0 & 0 \\
\hline \multicolumn{6}{|l|}{ Blood plasma } \\
\hline$n$ & 0 & 0 & 6.00 & 0 & 0 \\
\hline$\%$ & 0 & 0 & 100 & 0 & 0 \\
\hline \multicolumn{6}{|l|}{ Fundus } \\
\hline$n$ & 0 & 0 & 0 & 0 & 6.00 \\
\hline$\%$ & 0 & 0 & 0 & 0 & 100 \\
\hline \multicolumn{6}{|l|}{ Jejunum } \\
\hline$n$ & 0 & 0 & 0 & 0 & 6.00 \\
\hline$\%$ & 0 & 0 & 0 & 0 & 100 \\
\hline \multicolumn{6}{|l|}{ Colon } \\
\hline$n$ & 0 & 0 & 0 & 0 & 6.00 \\
\hline$\%$ & 0 & 0 & 0 & 0 & 100 \\
\hline \multicolumn{6}{|l|}{ Liver } \\
\hline$n$ & 0 & 0 & 0 & 0 & 6.00 \\
\hline$\%$ & 0 & 0 & 0 & 0 & 100 \\
\hline \multicolumn{6}{|l|}{ Kidney } \\
\hline$n$ & 0 & 0 & 0 & 3.00 & 3.00 \\
\hline$\%$ & 0 & 0 & 0 & 50.0 & $50 \cdot 0$ \\
\hline \multicolumn{6}{|l|}{ Pancreas } \\
\hline$n$ & 0 & 0 & 0 & 0 & 6.00 \\
\hline$\%$ & 0 & 0 & 0 & 0 & 100 \\
\hline \multicolumn{6}{|l|}{ Heart muscle } \\
\hline$n$ & 0 & 0 & 0 & 6.00 & 0 \\
\hline$\%$ & 0 & 0 & 0 & 100 & 0 \\
\hline \multicolumn{6}{|l|}{ Skeletal muscle } \\
\hline$n$ & 0 & 0 & 0 & 6.00 & 0 \\
\hline$\%$ & 0 & 0 & 0 & 100 & 0 \\
\hline \multicolumn{6}{|l|}{ Thymus } \\
\hline$n$ & 0 & 0 & 0 & 5.00 & 1.00 \\
\hline$\%$ & 0 & 0 & 0 & $83 \cdot 3$ & $16 \cdot 7$ \\
\hline \multicolumn{6}{|l|}{ Mesenteric lymph nodes } \\
\hline$n$ & 0 & 0 & 0 & 6.00 & 0 \\
\hline$\%$ & 0 & 0 & 0 & 100 & 0 \\
\hline \multicolumn{6}{|l|}{ Spleen } \\
\hline$n$ & 0 & 0 & 0 & 6.00 & 0 \\
\hline$\%$ & 0 & 0 & 0 & 100 & 0 \\
\hline \multicolumn{6}{|l|}{ Epidermis } \\
\hline$n$ & 0 & 0 & 0 & 6.00 & 0 \\
\hline$\%$ & 0 & 0 & 0 & 100 & 0 \\
\hline
\end{tabular}

${ }^{*} n$, absolute number of within-cluster mean values from a respective feeding group associated with one or more empirical clusters; \%, percentage amount of withincluster mean values from a respective feeding group associated with one or more empirical clusters; ninety $\mathrm{Zn}$ concentration values per $\mathrm{Zn}$ feeding group (28.1, 33.6, $38 \cdot 8,42 \cdot 7,47 \cdot 5,58 \cdot 2,67.8$ and $88.0 \mathrm{mg} \mathrm{Zn} / \mathrm{kg}$ diet) were considered yielding a total of 720 data points.

data on the response of certain $\mathrm{Zn}$ transporters within the kidney indicated a controlled up-regulation of $\mathrm{Zn}$ recycling from the primary urine and, at the same time, an increase in $\mathrm{Zn}$ transport towards the circulation ${ }^{(24)}$. It can be concluded that the kidney plays a key role within the network of whole-body Zn homoeostasis.

The present study highlighted obvious differences in the response of tissue $\mathrm{Zn}$ concentrations between the small and the large intestine. Jejunal $\mathrm{Zn}$ responded in a direct linear fashion to changes in dietary $\mathrm{Zn}$ concentration (thereby following the pattern of bone $\mathrm{Zn}$ depletion ${ }^{(8)}$ ), whereas colonic $\mathrm{Zn}$ expressed a broken-line response whose break point equalled that of apparently digested feed $\mathrm{Zn}^{(8)}$. Interestingly, studying $\mathrm{Zn}$ transporter gene expression (namely, the response of porcine solute carrier family (SLC) 39 member A4 (ZIP4)) indicated a significant non-linear response to the dietary $\mathrm{Zn}$ supply within the colon, but no significant regulation of the jejunal expression pattern under the present experimental conditions ${ }^{(24)}$. Furthermore, the colonic ZIP4 expression showed a highly significant negative correlation with the apparent $\mathrm{Zn}$ digestion $(r-0.91$, $P=0.002)^{(24)}$. In a former study, Pfaffl \& Windisch ${ }^{(25)}$ speculated about a potential shift in the main $\mathrm{Zn}$ absorption site from the small to the large intestine during the early stages of $\mathrm{Zn}$ deficiency. The authors based their assumption on peaks in the colonic expression of certain $\mathrm{Zn}$ responsive genes. Other groups demonstrated that the large intestine contributes to $\mathrm{Zn}$ absorption in times of impaired absorption from the small intestine $^{(26,27)}$. Furthermore, certain digestive enzymes, like carboxypeptidases A and B, need Zn as catalytic cofactor ${ }^{28-30)}$. In light of earlier data regarding the loss in digestive capacity in response to $\mathrm{SZD}^{(9,12)}$, we hypothesise the organism shifted its main absorption site of $\mathrm{Zn}$ to the lower intestinal segments as an attempt to maintain the already impaired digestive capacity.

The response of colon $\mathrm{Zn}$ concentration in the group receiving $33.6 \mathrm{mg} \mathrm{Zn} / \mathrm{kg}$ diet was completely different from the response of the six highest supplied groups $(38.8-88.0 \mathrm{mg}$ $\mathrm{Zn} / \mathrm{kg}$ diet) and of the lowest supplied group (28.1 mg Zn/kg diet). This peak may have indicated an increased $\mathrm{Zn}$ uptake in this group. In good context to that, colonic metallothionein gene expression ( $M T 1 A$ and $M T 2 B$ ) also peaked in animals fed $33.6 \mathrm{mg} \mathrm{Zn} / \mathrm{kg}$ diet (data not shown). Therefore, we conclude this finding was not due to analytical bias. The reason for this high $\mathrm{Zn}$ load remains yet unclear. Based on earlier data, the apparent feed $\mathrm{Zn}$ digestion in this group was slightly negative, indicating these animals excreted more $\mathrm{Zn}$ with the faeces than they ingested with the $\operatorname{diet}^{(8)}$. Windisch \& Kirchgessner ${ }^{(22)}$ demonstrated that dietary phytate concentrations of $9 \mathrm{~g} / \mathrm{kg}$ (which have been applied in the present study ${ }^{(8)}$ ) completely eliminate the true absorption of native dietary $\mathrm{Zn}$ from the gastrointestinal tract. Therefore, we conclude the observed $\mathrm{Zn}$ uptake within the colonic mucosa of animals fed $33.6 \mathrm{mg} \mathrm{Zn/kg}$ diet occurred from the basolateral rather than the apical side. Gene expression data obtained from the same tissue samples indicated a numerical up-regulation of SLC39A14 (ZIP14) with decreasing dietary $\mathrm{Zn}$ supply below the gross $\mathrm{Zn}$ requirement threshold $\left(58 \mathrm{mg} \mathrm{Zn/kg} \mathrm{diet)}{ }^{(24)}\right.$. This transporter is associated with the basolateral side of plasma membranes, where it pumps $\mathrm{Zn}$ from the circulation towards the cytosol ${ }^{(31,32)}$. Interestingly, Guthrie et al. ${ }^{(32)}$ demonstrated that the ZIP14 may be involved in the maintenance of intestinal barrier function, by demonstrating an increase in mucosal permeability in $\mathrm{ZIP}^{-14^{--}}$mice. Other studies showed clear connections between the Zn supply and the status of gut permeability ${ }^{(33-35)}$. Therefore, the observed peak in colonic $\mathrm{Zn}$ concentration in animals fed $33.6 \mathrm{mg} \mathrm{Zn} / \mathrm{kg}$ diet may reflect a compensation reaction to stabilise gut permeability. However, we did not see such a peak 
in the lowest supplied group (28.1 $\mathrm{mg} \mathrm{Zn} / \mathrm{kg}$ diet). This group expressed the strongest negative apparent $\mathrm{Zn}$ digestion together with the strongest bone $\mathrm{Zn}$ depletion ${ }^{(8)}$. Hence, its colon may have already been forced to reduce its $\mathrm{Zn}$ concentration to an inevitable minimum by 'donating' it to other tissues (e.g. the heart muscle). Indeed, this has yet to be proven in further studies.

To our knowledge, this is the first time the Zn supply status in response to varying dietary $\mathrm{Zn}$ supply was mapped by cluster analysis of body $\mathrm{Zn}$ pools. Interestingly, the sufficiently supplied groups (>58.0 mg Zn/kg diet) were not represented by one single cluster but three distinct clusters. These separated the majority of animals (83.3\%) supplied with the highest dietary $\mathrm{Zn}$ supply $(88.0 \mathrm{mg} \mathrm{Zn} / \mathrm{kg}$ diet) in cluster 5 from the other sufficiently supplied animals in clusters 4 and 6 . This is in agreement with specific response patterns of certain matrices, which pointed towards a different response of animals receiving 58.2 and $67.8 \mathrm{mg} \mathrm{Zn/} \mathrm{kg}$ diet relative to control $(88.0 \mathrm{mg} \mathrm{Zn/}$ kg diet) (e.g. jejunum and kidney). This could be explained by earlier data on the kinetics of $\mathrm{Zn}$ homoeostatic regulation over time. As has been demonstrated earlier, a full adaption of whole-body $\mathrm{Zn}$ homoeostasis to changes in dietary Zn supply (as expressed by an up-regulation of absorptive capacity together with a decrease in endogenous losses) happens within approximately $3-5 \mathrm{~d}^{(18,36-41)}$. This means every decrease in dietary Zn supply, even within ranges that would still be sufficient on a long-term scale, induces a short-term lack of absorbed dietary $\mathrm{Zn}$, which is compensated mainly by $\mathrm{Zn}$ mobilisation from the skeleton. This aspect has already been discussed in more detail in an earlier publication ${ }^{(8)}$. Furthermore, also the deficiently supplied groups ( $<58 \mathrm{mg} \mathrm{Zn} / \mathrm{kg}$ diet) were not represented by only one but three distinct clusters, which showed a gradual distribution of animals of the five lowest supplied groups. This hints again towards different physiological states in response to varying alimentary $\mathrm{Zn}$ supply, especially between animals receiving $28.1 \mathrm{mg} \mathrm{Zn/kg} \mathrm{diet}$ compared to 33.6 and $38.8 \mathrm{mg} \mathrm{Zn/kg}$ diet as well as 42.7 and $47.5 \mathrm{mg} \mathrm{Zn} / \mathrm{kg}$ diet, respectively, based on the respective frequency tabulation. This is in good context to our earlier data on the response of cardiac redox metabolism ${ }^{(10)}$. The lowest $\mathrm{Zn}$ supplied groups already showed first signs of subclinical pathophysiological adaption (loss in cardiac antioxidative capacity, up-regulation of stress-responsive genes), whereas $>40 \mathrm{mg} \mathrm{Zn/kg} \mathrm{diet} \mathrm{animals} \mathrm{still} \mathrm{expressed} \mathrm{a} \mathrm{basal} \mathrm{physiological}$ status $^{(10)}$.

Clustering our data over biological matrices separated the excretion, storage and distribution media (faeces, bone, plasma) from each other and soft tissues, respectively. However, the soft tissues were not represented by one single cluster but two. Based on the respective frequency tabulation, one of these clusters (cluster 5) was mainly represented by tissues of $\mathrm{Zn}$ metabolism by being involved in $\mathrm{Zn}$ acquisition (fundus, jejunum and colon), excretion (pancreas) or redistribution (liver), respectively. The other cluster (cluster 4) appears to be mainly represented by tissues that are important for the acute survival of the organism (heart muscle, skeletal muscle, lymph follicles, thymus, spleen and epidermis) and in which $\mathrm{Zn}$ concentrations may have been affected by the tissues of $\mathrm{Zn}$ metabolism.
Although the already discussed regression data and the frequency tabulation of cluster composition appear to be in good context, the discrimination between clusters 4 and 5 was not very good based on the display of the relationship between canonical variables 1 and 2 . Therefore, these results must be considered with caution.

The present study comprised varying supplementation of zinc sulphate to healthy animals. However, infections or different dietary $\mathrm{Zn}$ sources presumably would have changed the outcome of our study. Earlier published data suggest plasma hypozincaemia during systemic inflammation by SLC39A14 (ZIP14) activity at the basolateral membrane of hepatocytes $^{(31,42)}$. Own data on $\mathrm{Zn}$ transporter gene expression in different tissues indicate certain transporters to be regulated by the stress status of a tissue rather than the $\mathrm{Zn}$ supply status of the $\operatorname{organism}^{(24)}$. Hence, inflammatory processes have the potential to change the distribution of body $\mathrm{Zn}$ and may be able to interfere with the response to dietary $\mathrm{Zn}$ restriction. A variable bioavailability of the feed $\mathrm{Zn}$ might have also changed the current data set. A higher or lower available $Z$ n source could have slowed down or increased $\mathrm{Zn}$ depletion over time, respectively. Hence, the above described dietary thresholds would have been altered. However, the hierarchy of body $\mathrm{Zn}$ redistribution would presumably not have been changed. In times of limited body $\mathrm{Zn}$ stores, the organism would expectedly favour tissues that are crucial for the acute survival in advance of others.

\section{Conclusion}

During the present study, novel response patterns of the adaption of tissue $\mathrm{Zn}$ concentration have been recognised. These included the replenishment and accumulation of $\mathrm{Zn}$ concentrations in tissues that are important for the acute survival of the developing organism (heart muscle, skeletal muscle, immune tissues and pancreas). This appears to have happened due to other body compartments 'donating' their $\mathrm{Zn}$ to these tissues during limited dietary Zn supply, which might indicate compensation reactions in times of increased cellular stress. Furthermore, this is to our knowledge the first study that mapped the gross $\mathrm{Zn}$ requirement by clustering tissue $\mathrm{Zn}$ concentrations between treatment groups. Clustering groups of biological matrices discriminated between excretion, storage and transport media as well as soft tissues. The present study highlights for the first time the dose-dependent kinetics of body Zn depletion and redistribution during short-term SZD in growing individuals. Given their high similarity regarding nutrition physiology, these data may be likely translated from pigs to humans.

\section{Acknowledgements}

The authors thank the Bayerische Arbeitsgemeinschaft Tierernährung (BAT) e.V. for the generous support of this study. BAT e.V. had no role in the design, analysis or writing of this article. Furthermore, the authors would like to express their deepest gratitude to Dr Astrid Kunert, Dr Martin Hanauer, Johanna Ortner, MSc, Anna Dettweiler, BSc, Maria Hechfellner, 
BSc, Vanessa Straub, BSc, Dipl. Ing. (FH) Michael Gertitschke and Andrea Reichlmeir for excellent technical assistance. Special gratitude is related to Brett Boden, BSc, for valuable advice on the manuscript.

D. B. designed and conducted the experiment, supervised the chemical analyses, analysed and interpreted the data and wrote the manuscript; and W. M. W. was the principal investigator and had primary responsibility for the final content.

The authors declare no conflicts of interest which could have biased their work.

\section{Supplementary material}

For supplementary material/s referred to in this article, please visit https://doi.org/10.1017/S0007114519000187

\section{References}

1. National Research Council (1994) Nutrient Requirements of Poultry, vol. 9. Washington, DC: National Academies Press.

2. National Research Council (2000) Nutrient Requirments of Beef Cattle, vol. 7. Washington, DC: National Academies Press.

3. National Research Council (2001) Nutrient Requirments of Dairy Cattle. Washington, DC: National Academies Press.

4. National Research Council (2006) Nutrient Requirments of Small Ruminants: Sheep, Goats, Cervids, and New World Camelids. Washington, DC: National Academies Press.

5. National Research Council (2011) Nutrient Requirements of Fish and Shrimp. Washington, DC: National Academies Press.

6. National Research Council (2012) Nutrient Requirements of Swine, 11th ed. Washington, DC: National Academies Press.

7. Prasad AS (1985) Clinical manifestations of zinc deficiency. Annu Rev Nutr 5, 341-363.

8. Brugger D, Buffler M \& Windisch W (2014) Development of an experimental model to assess the bioavailability of zinc in practical piglet diets. Arch Anim Nutr 68, 73-92.

9. Brugger D \& Windisch W (2016) Subclinical zinc deficiency impairs pancreatic digestive enzyme activity and digestive capacity of weaned piglets. Br J Nutr 116, 425-433.

10. Brugger D \& Windisch W (2017) Short-term subclincial zinc deficiency in weaned piglets affects cardiac redox metabolism and zinc concentration. $J$ Nutr 147, 521-527.

11. Nielsen KL, Hartvigsen ML, Hedemann MS, et al. (2014) Similiar metabolic responses in pigs and humans to breads with different contents and compositions of idetary fibers: a metabolomics study. Am J Clin Nutr 99, 941-949.

12. Brugger D \& Windisch W (2016) Subclinical zinc deficiency impairs pancreatic digestive enzyme activity and digestive capacity of weaned piglets - Corrigendum. Br J Nutr 116, 950-951.

13. Robbins KR, Saxton AM \& Southern LL (2006) Estimation of nutrient requirements using broken-line regression analysis. J Anim Sci 84, E155-E165.

14. McDonald JH (2014) Power Analysis. In Handbook of Biological Statistics, 3rd ed., pp. 40-44 [JH McDonald, editor]. Baltimore, MD: Sparky House Publishing.

15. Institue Inc SAS (2017) Cubic clustering criterion. In $S A S^{\infty}$ Enterprise Miner ${ }^{\mathrm{TM}}$ 143: Reference Help, pp. 113-150 [SI Inc., editor]. Cary, NC: SAS Institute Inc.

16. Giugliano R \& Millward DJ (1984) Growth and zinc homeostasis in the severely Zn-deficient rat. Br J Nutr 52, 545-560.

17. Windisch W \& Kirchgessner M (1994) Distribution and exchange of zinc in different tissue fractions at deficient and excessive zinc supply 3 . Effect of different zinc supply on quantitative zinc exchange in the metabolism of adult rats. J Anim Physiol Anim Nutr 71, 131-139.

18. Windisch W \& Kirchgessner M (1999) Tissue zinc distribution and exchange in adult rats at zinc deficiency induced by dietary phytate additions: II. Quantitative zinc metabolism of ${ }^{65} \mathrm{Zn}$ labelled adult rats at zinc deficiency. J Anim Physiol Anim Nutr 82, 116-124.

19. Andreini C, Banci L, Bertini I, et al. (2006) Counting the zincproteins encoded in the human genome. J Proteome Res $\mathbf{5}$, 196-201.

20. Hosea HJ, Rector ES \& Taylor CG (2007) Dietary zinc deficiency lowers the proportions of splenic CD90+ (Thy-1+) $\mathrm{B}$-cells and late thymic emigrant T-cells in growing rats. $\mathrm{Br} \mathrm{J}$ Nutr 98, 1108-1111.

21. Canton MC \& Cremin FM (1990) The effect of dietary zinc depletion and repletion on rats: $\mathrm{Zn}$ concentration in various tissues and activity of pancreatic gamma-glutamyl hydrolase (EC 3.4.22.12) as indices of Zn status. Br J Nutr $\mathbf{6 4}$, 201-209.

22. Windisch W \& Kirchgessner M (1999) Zinc absorption and excretion in adult rats at zinc deficiency induced by dietary phytate additions: I. Quantitative zinc metabolism of ${ }^{65} \mathrm{Zn}$ labelled adult rats at zinc deficiency. J Anim Physiol Anim Nutr 82, 106-115.

23. Weigand E \& Kirchgessner M (1980) Total true efficiency of zinc utilization: determination and homeostatic dependence upon the zinc supply status in young rats. J Nutr 110, 469-480.

24. Brugger D (2018) 6th chapter: Comparative analysis of zinc transporter gene expression in jejunum, colon, liver and kidney of weaned piglets challenged with subclinical zinc deficiency. In Experimental Modelling of Subclinical Zinc Deficiency in Weaned Piglets, pp. 171-208. PhD Dissertation, Technical University of Munich, Freising, Germany.

25. Pfaffl MW \& Windisch W (2003) Influence of zinc deficiency on the mRNA expression of zinc transporters in adult rats. J Trace Elem Med Biol 17, 97-106.

26. Hara H, Konishi A \& Kasai T (2000) Contribution of the cecum and colon to zinc absorption in rats. J Nutr 130, 83-89.

27. Martin AB, Aydemir TB, Guthrie GJ, et al. (2013) Gastric and colonic zinc transporter ZIP11 (Slc39a11) in mice responds to dietary zinc and exhibits nuclear localization. J Nutr 143, 1882-1888

28. Folk JE, Piez KA, Carroll WR, et al. (1960) Carboxy-peptidase B. 4. Purification and characterization of the porcine enzyme. J Biol Chem 235, 2272-2277.

29. Folk JE \& Schirmer EW (1963) The porcine pancreatic carboxypeptidase A system. I. Three forms of the active enzyme. J Biol Chem 238, 3884-3894.

30. Hsu J, Anilane JK \& Scanlan DE (1966) Pancreatic carboxypeptidases: activities in zinc deficient rats. Science $\mathbf{1 5 3}$, 882-883.

31. Liuzzi JP, Lichten LA, Rivera S, et al. (2005) Interleukin-6 regulates the zinc transporter Zip14 in liver and contributes to the hypozincemia of the acute-phase response. PNAS 102, 6843-6848

32. Guthrie GJ, Aydemir TB, Troche C, et al. (2015) Influence of ZIP14 (slc39A14) on intestinal zinc processing and barrier function. Am J Physiol Gastrointest Liver Physiol 308, G171-G178.

33. Zhang B \& Guo Y (2009) Supplemental zinc reduced intestinal permeability by enhancing occludin and zonula occludens protein-1 (ZO-1) expression in weaning piglets. Br J Nutr 102, 687-693.

34. Miyoshi Y, Tanabe S \& Suzuki T (2016) Cellular zinc is required for intestinal epithelial barrier maintenance via the regulation of claudin-3 and occludin expression. Am J Physiol Gastrointest Liver Physiol 311, G105-G116. 
35. Hennig B, Wang Y, Ramasamy S, et al. (1992) Zinc deficiency alters barrier function of cultured porcine endothelial cells. J Nutr 122, 1242-1247.

36. Windisch W (2001) Homeostatic reactions of quantitative $\mathrm{Zn}$ metabolism on deficiency and subsequent repletion with $\mathrm{Zn}$ in ${ }^{65} \mathrm{Zn}$-labeled adult rats. Trace Elem Elec 18, 122-128.

37. Windisch W \& Kirchgessner M (1994) Measurement of homeostatic adaption of $\mathrm{Zn}$ metabolism to deficient and high zinc supply after an alimentary ${ }^{65} \mathrm{Zn}$ labeling procedure. 1 . Effect of different zinc supply on the quantitative zinc exchange in the metabolism of adult rats. J Anim Physiol Anim Nutr 71, 98-107.

38. Windisch W \& Kirchgessner M (1995) Adjustments of Zn metabolism and of $Z n$ exchange kinetics in the whole body of ${ }^{65} \mathrm{Zn}$ labelled rats to varying levels of $\mathrm{Zn}$ intake. 1 . Study of the quantitative $\mathrm{Zn}$ exchange in the metabolism of adult rats at physiologically adequate Zn supplies. J Anim Physiol Anim Nutr 74, 101-112.

39. Windisch W \& Kirchgessner M (1995) Distribution and exchange of $\mathrm{Zn}$ in tissues of ${ }^{65} \mathrm{Zn}$ labelled rats. II.: Studies on the quantitative $\mathrm{Zn}$ exchange in the metabolism of adult rats at physiologically adequate Zn supplies. J Anim Physiol Anim Nutr 74, 113-122.

40. Windisch W (2003) Development of zinc deficiency in ${ }^{65} \mathrm{Zn}$ labeled, fully grown rats as a model for adult individuals. J Trace Elem Med Biol 17, 91-96.

41. Windisch W (2003) Effect of microbial phytase on the bioavailability of zinc in piglet diets. Proc Soc Nutr Physiol 12, 33 .

42. Liuzzi JP, Aydemir F, Nam H, et al. (2006) Zip14 (Slc39a14) mediates non-transferrin-bound iron uptake into cells. PNAS 103, 13612-13617. 